\title{
Nursing reflective practice: An empirical literature review
}

\author{
Véronique Dubé ${ }^{* 1}$, Francine Ducharme ${ }^{1,2}$ \\ ${ }^{1}$ Faculty of Nursing, Université de Montréal, Montreal, Canada \\ ${ }^{2}$ Research Centre, Institut universitaire de gériatrie de Montréal, Montreal, Canada
}

Received: April 1, 2015

Accepted: April 22, 2015

Online Published: May 11, 2015

DOI: $10.5430 /$ jnep.v5n7p91

URL: http://dx.doi.org/10.5430/jnep.v5n7p91

\begin{abstract}
Reflective practice is a widespread concept in nursing; however, few empirical studies have demonstrated the possible effects of such a practice. The goal of this article is to present a review of the empirical literature on nursing reflective practice. Thirty-seven studies published between 1995 and 2012 were selected and analyzed to identify their common characteristics and structure. Most of them are qualitative in nature and were conducted in an academic context. Generally, few authors clearly define the reflective practice concept and the frames of reference on which their research is based. Furthermore, when reflective practice interventions are described, they have few points of comparison, which makes it hard to choose which intervention to prioritize to maximize the positive effects on nursing practice. Although a lot has been written on the advantages of reflective practice, nursing research on this concept remains at an early stage. The authors recommend various paths for future research.
\end{abstract}

Key Words: Reflective practice, Reflection, Nursing, Professional development, Literature review

\section{INTRODUCTION}

Reflective practice has been gaining in popularity in nursing literature over the last twenty years. The concept, which emerged in the early 1990s in the United Kingdom, can be defined as a learning and development process that includes the self-examination of one's professional practice, including experiences, thoughts, emotions, actions and knowledge that enrich it. ${ }^{[1,2]}$

Certain authors attribute numerous qualities to reflective practice, including: the development of a form of knowledge rooted in the practice ${ }^{[3]}$ and recognition of nurses' expertise, ${ }^{[4]}$ the modification and improvement of clinical practices; ${ }^{[5,6]}$ the possibility of bridging the gap between theory and practice $^{[7]}$ and lastly, the development of a new learn- ing tool. ${ }^{[8-10]}$ Reflective practice can be stimulated through various strategies: verbal, written or a combination of both. Verbal strategies often refer to small workshops or clinical situations regarding issues raised by nurses, which are sources of discussion and learning. These workshops are usually led by a facilitator. Written strategies can take on various forms such as journals, reflective writings or portfolios. These strategies usually refer to a written activity during which the reflective practitioner describes and analyzes a clinical situation encountered while trying to highlight learning and development aspects of his practice, often accompanied by a frame of reference structuring his reflection.

For Rolfe, ${ }^{[11]}$ reflective practice goes beyond acquiring knowledge: it allows for knowledge to be critiqued while taking into account the sociocultural context. Reid ${ }^{[6]}$ states

\footnotetext{
* Correspondence: Véronique Dubé; Email: veronique.dube.1@umontreal.ca; Address: Faculty of Nursing, Université de Montréal, PO Box 6128, Station Centre-ville, Montréal, Québec, H3C 3J7, Canada.
} 
that reflective practice helps to examine the care activities that are taken for granted and prevents nurses from getting caught in the trap of assumption, ritualization, habituation and routine. This is why reflective practice is increasingly valued in nursing programs and is strongly encouraged as a means for the professional development of experienced nurses. ${ }^{[4,12,13]}$ Certain professional associations even encourage nurses to adopt reflective practice in order to maintain their skills. ${ }^{[14-16]}$

However, the many qualities associated with reflective practice still remain anecdotal. Few empirical studies have been conducted on reflective practice and there have been even fewer evaluative studies that examine its effects on nursing practice. This article aims to establish the current state of empirical knowledge on reflective practice in order to identify areas for nursing research.

\section{METHODS}

A search was done in the Cumulative Index to Nursing and Allied Health Literature [CINAHL] and MEDLINE databases using "reflection and professional practice" or "reflection and nursing practice" as descriptors regardless of the publication date of the articles. By focusing our search only on empirical nursing studies, 200 English and French articles addressing reflective practice in nursing were identified in the CINAHL database and 216 in the MEDLINE database. Of these 416 articles, we eliminated the duplicates $(n=201)$. Based on their title and abstract, the empirical articles selected $(n=215)$ had to mainly pertain to: 1$)$ the development, testing or evaluation of a reflective practice in nursing; 2) one or more strategies for developing a reflective practice (e.g., journals, portfolios, workshops) and; 3) be conducted with pre- or post-registration nursing students in an academic environment or with registered nurses in a clinical environment. Studies on the reflective practice of educators or researchers were excluded from the analysis. We performed an analysis of 37 articles most of which (n = 16) came from the United Kingdom. Table 1 shows the criteria used to evaluate the studies, and Table 2 shows the 37 articles selected.

Table 1. Evaluation criteria of the articles selected

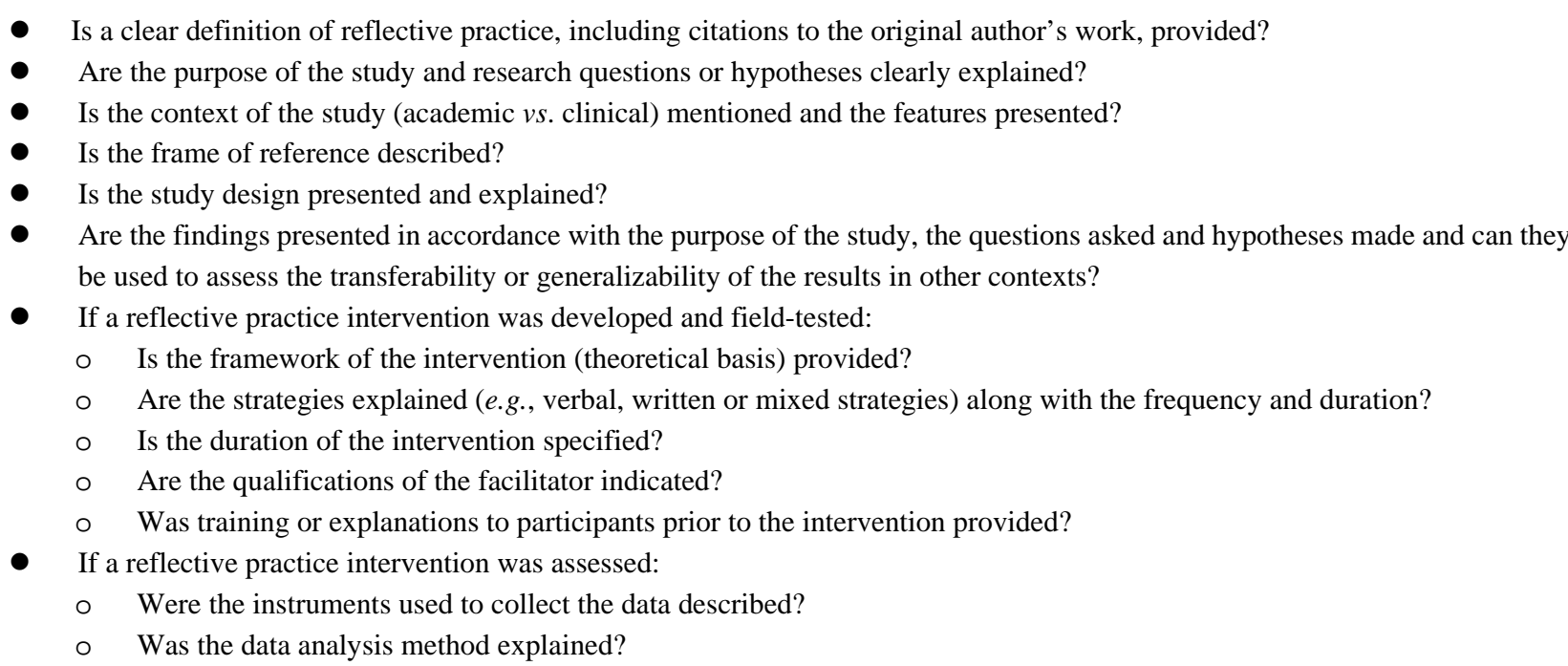

\section{RESUlts}

The results of our analysis of the empirical articles are presented according to their main features, namely: purpose, context, definition of reflective practice, frames of reference used, design and main findings of these studies.

\subsection{Definitions and frames of reference}

In defining reflective practice, most authors based themselves on established theoretical writings such as those by Boud, Keogh, and Walker, ${ }^{[24]}$ Boyd and Fales, ${ }^{[5]}$ Dewey, ${ }^{[77]}$
Mezirow, ${ }^{[23,58,71]} \operatorname{Reid}^{[6]}$ and Schön ${ }^{[7,65]}$ (see Table 3 for definitions), although in nine studies, no specific definition of reflective practice was provided.

The reflective practice definitions identified in the studies all recognize the experiences of reflective practitioners as the basis for new learning. In most studies, the reflection process refers to Schön's reflection-in-action (reflection during a clinical experience) and reflection-on-action (reflection on a clinical experience after the fact). ${ }^{[7]}$ 
Table 2. Research synthesis on reflective practice $(\mathrm{RP})(\mathrm{n}=37)$

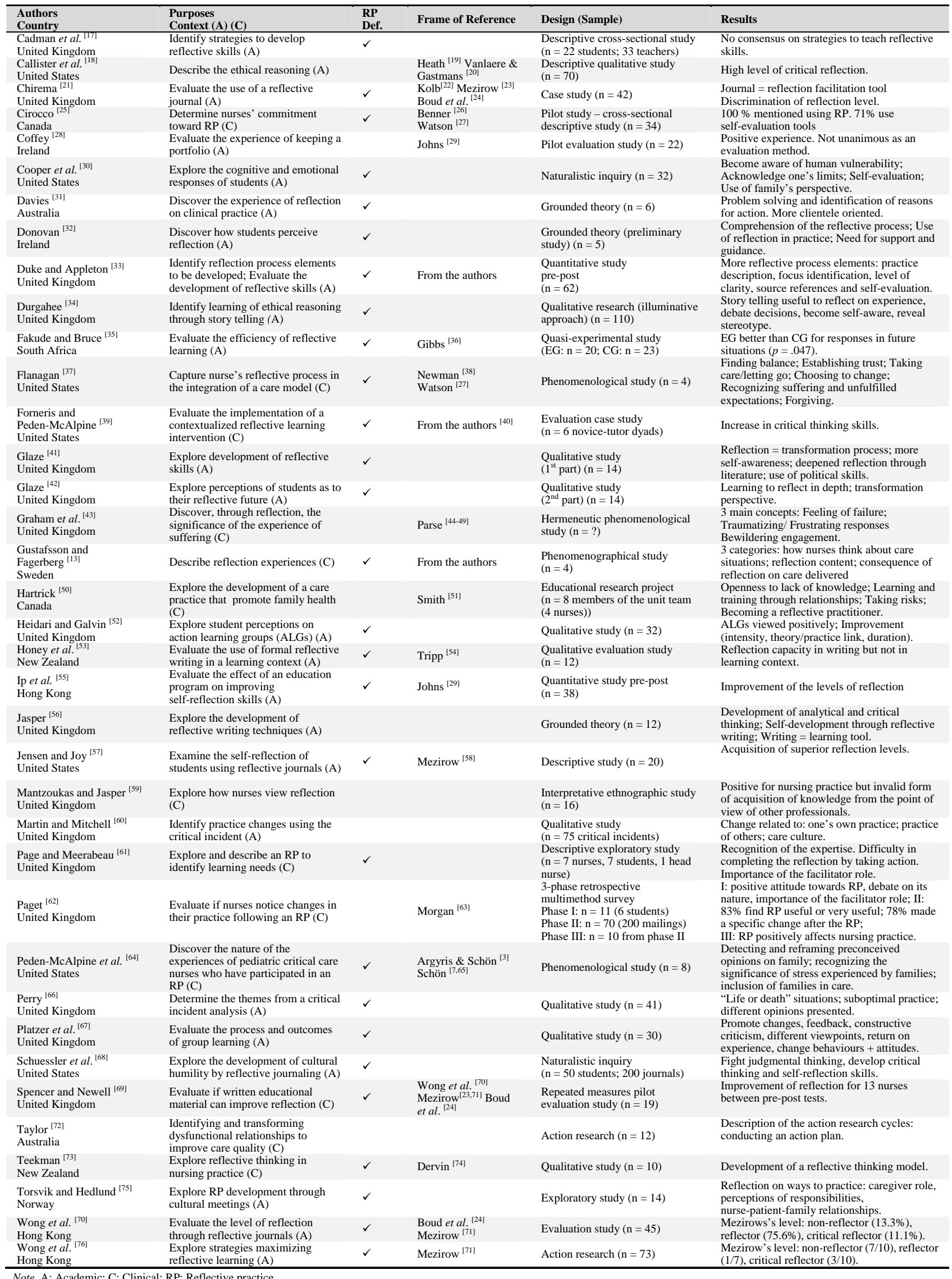

Note. A: Academic; C: Clinical; RP: Reflective practice.

Published by Sciedu Press 
Moreover, many studies refer to reflection levels and consider that the reflection can be categorized according to varying levels of intensity. Many of these writings are based on the work of Boud et al., ${ }^{[24]}$ which proposes a reflection process comprising six elements, namely analysis of emotions association, integration, validation, appropriation and the results of the reflection, while others are based on the work of Mezirow, ${ }^{[71]}$ which indicate that the reflection process can operate at various levels of intensity: habitual action, thoughtful action/understanding, reflection or critical reflec- tion.

Various reflective practice frames of reference were also used in the studies selected. These frames of reference mainly served to facilitate the learner's reflection ${ }^{[29,36]}$ by guiding the reflection with a series of questions (for example: What were you thinking and feeling? What else could you have done?). Others are used to categorize reflective practitioners according to the reflection level reached following a written reflective activity. ${ }^{[23,24,71]}$ However, many studies did not include an explicit frame of reference.

Table 3. Definitions of reflection or reflective practice by influential authors in the field

\begin{tabular}{|c|c|}
\hline Authors & Definitions \\
\hline Boud et al. ${ }^{[24]}$ & $\begin{array}{l}\text { "A generic term for those intellectual and affective activities in which individuals engage to explore their } \\
\text { experiences in order to lead to a new understanding and appreciation.” (p. 19) }\end{array}$ \\
\hline Boyd and Fales ${ }^{[5]}$ & $\begin{array}{l}\text { "The process of creating and clarifying the meanings of experiences in terms of self in relation to both self and } \\
\text { world. The outcome of this process is changed conceptual perspectives." (p. 101) }\end{array}$ \\
\hline Dewey ${ }^{[77]}$ & $\begin{array}{l}\text { "Active, persistent, and careful consideration of any belief or supposed form of knowledge in the light of the } \\
\text { grounds that support it and the further conclusions to which it tends [that] includes a conscious and voluntary } \\
\text { effort to establish belief upon a firm basis of evidence and rationality.” (p. 9) }\end{array}$ \\
\hline Mezirow $^{[71]}$ & $\begin{array}{l}\text { "Reflection is the central dynamic in intentional learning, problem solving, and validity testing through rational } \\
\text { discourse. Intentional learning centrally involves either the explication of meaning of an experience, } \\
\text { reinterpretation of that meaning, or application of it in thoughtful action." (p. 99) }\end{array}$ \\
\hline Reid $^{[6]}$ & $\begin{array}{l}\text { "Reflection is a process of reviewing an experience of practice in order to describe, analyse, evaluate and so } \\
\text { inform learning about practice." (p. 305) }\end{array}$ \\
\hline Schön ${ }^{[7]}$ & $\begin{array}{l}\text { "The practitioner allows himself to experience surprise, puzzlement, or confusion in a situation which he finds } \\
\text { uncertain or unique. He reflects on the phenomenon before him, and on the prior understandings which have } \\
\text { been implicit in his behaviour. He carries out an experiment which serves to generate both a new understanding } \\
\text { of the phenomenon and a change in the situation." (p. 68) Reflection in action is to think what they are doing } \\
\text { while they are doing it. Reflection on action is looking back after the event. }\end{array}$ \\
\hline
\end{tabular}

3.2 Reflective practice approach preferred in the studies In 22 studies, a specific reflective practice intervention was field-tested. However, with the exception of the PedenMcAlpine, Tomlinson, Forneris, Genck, and Meiers, ${ }^{[64]}$ Forneris and Peden-McAlpine ${ }^{[39]}$ and Ip et al. ${ }^{[55]}$ studies, details regarding the reflective practice intervention were not fully described.

When specified by the authors, numerous strategies were selected for the reflective practice intervention, namely verbal (e.g., group workshops), ${ }^{[34,52,61,67]}$ written (e.g., reflective journal $)^{[18,21,30,53,56,68,70]}$ or mixed strategies. ${ }^{[39,50,55,64,72,75]}$ The intensity of the interventions varied across the studies, namely the frequency of the strategies selected and the duration of the intervention. However, many of the studies did not specify how the nurses were initiated to reflective practice.

\subsection{Context, purpose, and design}

Studies dealing with reflective practice in nursing were for the most part conducted in an academic context $(n=24)$, either with students aspiring to become nurses ${ }^{[30,35,55,68]}$ or with post-registration nursing students. ${ }^{[21,28,33,42,53,60,70,76]}$ In the field of nursing education, studies have been especially interested in reflective practice as a teaching strategy to promote a learning approach rooted in the experience of students, thereby aiming to bridge the gap between nursing theory and practice. Of the 24 empirical studies identified, most $(n=18)$ were conducted using a qualitative approach. These studies dealt with the student nurse perception of their reflective practice experience; on the development of reflective skills, as well as the effects of a reflective practice.

A smaller number of studies $(n=13)$ were conducted in a clinical context. ${ }^{[13,25,37,39,43,50,59,61,62,64,69,72,73]}$ Most $(\mathrm{n}=$ 10) were also conducted using a qualitative approach. Among these studies, some were focused on understanding the reflective process experience of nurses in various care situations, ${ }^{[13,37,43,59,64,73]}$ while others focused on the development and implementation of a reflective practice to identify learning needs ${ }^{[61]}$ or care improvement needs. ${ }^{[72]}$ A qualitative evaluation of a reflective practice intervention to improve 
clinical reasoning among novice nurses was also the subject of one study. ${ }^{[39]}$

Among the rare published quantitative studies, Cirocco ${ }^{[25]}$ sought to determine the nurses' commitment $(n=34)$ toward reflective practice, Paget ${ }^{[62]}$ evaluated the nurses' perception $(n=70)$ of changes in their clinical practice following the use of a reflective practice and Spencer and Newell ${ }^{[69]}$ evaluated the improvement of reflective skills among nurses $(n=19)$ using written educational material on reflection.

As far as the methods used for both the qualitative and quantitative studies, data were most often collected using one-on-one interviews, ${ }^{[21,31,32,39,42,50,64,73,76]}$ focus groups, ${ }^{[34,39,52,56,67,75]}$ written reflective works such as student journals or critical incidents reported by nurses. ${ }^{[18,21,30,33,39,50,53,55,57,60,66,68-70,72]}$ In terms of data analysis, the qualitative studies used mainly thematic content analyses, ${ }^{[18,30,52,62,66,67,70]}$ but many of them barely explained the preferred approach for the analysis. ${ }^{[28,50,61,72,76]}$ The sample size varied between 4 and 110 nurses for the qualitative studies and between 34 and 70 nurses for the quantitative studies. Some researchers thereby warn against generalizing the results as most used a small convenience sample size.

\subsection{Main results of the qualitative studies}

The qualitative studies conducted by Davies, ${ }^{[31]}$ Durgahee $^{[34]}$ and Heidari and Galvin ${ }^{[52]}$ in an academic environment show that student nurses appreciate their reflective practice experience overall, regardless of whether the experience was conducted using verbal (e.g., reflective sessions, focus groups, active learning groups), written (e.g., reflective journals) or mixed strategies. Students stress the significant amount of time needed to reflect using written strategies, but recognize the contribution of reflective practice in their professional practice. This type of practice helps to identify negative attitudes and areas of improvement, promote change in professional practices and put patients at the heart of the learning activity. Studies conducted by Callister et al., ${ }^{[18]}$ Cooper $e t$ al.,${ }^{[30]}$ Honey et al. ${ }^{[53]}$ Glaze, ${ }^{[42]}$ Schuessler et al.,${ }^{[6]}$ and Wong et al., ${ }^{[76]}$ show that student nurses managed to develop diversified reflective skills following a reflective practice in an academic context, such as self-awareness, openness to others and their practices, and the various emotions experienced in a learning context, such as fear or anxiety. The study conducted by Platzer et al. ${ }^{[67]}$ found that reflective practice groups promoted emotional support, reassurance, feedback, encouragement and constructive criticism by peers where student nurses are concerned. These groups also seem to allow for a change of behaviours and attitudes among participants. In the same study, the students mentioned being open- minded, using critical thinking, being more self-confident and having a sense of legitimacy in using their knowledge in their practice. Reflective practice seems to be a new learning tool that is valued by nurses and a lever of change offering students the opportunity to examine their assumptions and develop different reflective skills.

The contribution of reflective practice was also demonstrated in the few studies conducted in a clinical environment. Three qualitative studies ${ }^{[13,37,73]}$ dealt with understanding the use of reflection among nurses. These studies demonstrated that nurses use reflection as part of their professional activities and that it allows them to reflect during and after an action and with varying goals, such as taking action, evaluating or reviewing their practice. However, in these studies, no prior training was offered to guide the reflection process of the nurses or to make sure that they had skills needed to carry out a reflexive process. It was assumed that the nurses intuitively possessed these skills and were familiar with reflective practice.

Other results were extracted from qualitative studies conducted in a clinical environment. During the development of a reflective practice with nurses in practice, Hartrick ${ }^{[50]}$ thereby concluded that the greatest outcome of his educational experience was the profound transformation of the participants' attitude with regard to promotion of family health. As for the study conducted by Page and Meerabeau, ${ }^{[61]}$ it failed to demonstrate any practice transformation, as the nurses only managed to identify their practice's improvement areas without taking action or making concrete changes in their professional practice. Mantzoukas and Jasper ${ }^{[59]}$ showed that the culture of certain care units do not promote reflective practice in nursing as some professionals deem it to be an invalid knowledge acquisition method. However, two qualitative evaluation research projects ${ }^{[39,64]}$ also conducted in a clinical environment showed that nurses had, among other things, improved their critical thinking skills during the first 6 months of their practice and began to incorporate patient families into nursing care following the use of reflective practice.

Based on the results of these qualitative studies, we can deduce that reflective practice, using both verbal and written strategies, is a learning tool appreciated by a large majority of nurses although it requires a certain investment of time. It provides support from peers during new learning, the development of various reflexive skills such as self-awareness, openness to others and their practice, critical thinking and the change of certain professional practices, but must take into account the culture of the environment where it is implemented. 


\subsection{Main results of the quantitative studies}

A few quantitative studies also included complementary results with these qualitative data. Using a retrospective survey of 70 nurses, Paget ${ }^{[62]}$ thereby concluded that nurses who use reflective practice perceive it as useful (83\%) and having a positive effect on their practice $(73 \%)$. However, the study fails to identify which aspects of their practice the nurses changed and how this practice had positive effects on the care delivered to clients.

Chirema, ${ }^{[21]}$ Fakude and Bruce, ${ }^{[35]}$ Ip et al.,${ }^{[55]}$ Jensen and Joy, ${ }^{[57]}$ Spencer and Newell ${ }^{[69]}$ and Wong et al. ${ }^{[70]}$ revealed a few positive effects of reflective practice on the progression of the reflection level among student nurses and registered nurses. However, with the exception of Ip et al. ${ }^{[55]}$ study, these studies only evaluated the reflection level using a crosssectional design. No longitudinal study has yet to document the evolution of reflection over a longer period of time or the achievement of a higher reflection level after a reflective practice intervention.

In short, most of the studies identified are qualitative, exploratory or descriptive and were conducted in an academic context (see Table 2 for a summary of these studies). Reflective practice interventions are still not explicit in most of the studies identified. Most of these studies also present theoretical and methodological weaknesses as they fail to specify definitions and frames of reference, or data collection tools and analysis methods. It is therefore difficult to establish comparisons between each of the studies. Although reflective practice appears to be a learning tool valued by nurses, allows for the development of certain reflexive skills and the progression of the level of reflection in practitioners, very few evaluative studies on reflective practice focus on its effects on nursing interventions, and none of them have evaluated the possible outcomes of reflective practice on patient care.

\section{Discussion}

As mentioned, the reflective practice studies reviewed to date were used to explore, describe and assess certain aspects of a reflective practice in an academic and clinical context. However, studies specifying: a) a more explicit definition and frame of reference of reflective practice; b) the operationalization of reflective practice in terms of the verbal and written strategies selected; c) the reflective skills and the prior training of nurses in terms of reflective practice; d) the duration and frequency of the strategies selected for the implementation of a reflective practice and; e) the characteristics of the support offered in the various environments, should be used to better guide the development of knowledge in this research area.

The concept of reflective practice has never been clearly defined in empirical literature. A consensus on a common definition of reflective practice is essential for nursing education. Frames of reference that better structure the reflective practice appropriation and integration process by nurses should also be promoted. For example, Johns' or Gibbs' frame of reference ${ }^{[29,36]}$ seem to facilitate the reflective approach among nurses through their question-based structure (e.g., What was good and bad about the experience? What knowledge did or could have informed me?). The evaluation of the achievement of higher reflection levels as proposed by Boud et al. $^{[31]}$ and Mezirow ${ }^{[24]}$ also seems promising. However, studies on the refinement of these theoretical perspectives should be conducted.

A combination of verbal and written reflective practice strategies seems essential for positive outcomes, although verbal strategies are more appreciated than written ones by nurses. Training activities with coaching and feedback helping to prepare for these written exercises could make reflective writing less strenuous and allow for the development of reflective skills. As the duration and frequency of the strategies implemented also vary between studies, the best approaches have yet to be determined. Some studies also raise the importance of the role played by facilitators during the implementation of reflective practice, but few writings focus on the skill set coaches need to get nurses to adhere to this practice. Therefore, studies specifying the optimal features of reflective practice interventions in terms of strategies, duration, frequency, coaching (qualifications) and the prerequisites for a reflective practice (training) should be carried out.

\section{Conclusion}

Although many writings deal with reflective practice and recognize its numerous qualities, nursing research in this field remains rudimentary. This research is even rarer when we limit reflective practice to practice environments. Stemming from works conducted mainly in academic environments, reflective practice has yet to be fully recognized as a form of professional development. Clinical environments would thereby benefit from an evaluation of its outcomes, for example, on integrating innovative care interventions based on best practices or patient-centered care. Numerous research areas need to be explored. This article proposes some promising areas of reflective practice knowledge development.

\section{CONFLICTS OF INTEREST DiSCLOSURE}

The authors declare that there is no conflict of interest statement. 


\section{REFERENCES}

[1] Atkins S. Developing underlying skills in the move towards reflective practice. In C. Bulman \& S. Schutz (dir.), Reflective practice in nursing (3rd ed., p. 25-46). Oxford: Blackwell Publishing; 2004.

[2] Duffy A. A concept analysis of reflective practice: Determining its value to nurses. British Journal of Nursing. 2007; 16(22): 1400-1407. http://dx.doi.org/10.12968/bjon.2007.16.22.27771

[3] Argyris C, Schön DA. Theory in practice: Increasing professional effectiveness. (1st ed.). San Francisco, CA: Jossey-Bass; 1974.

[4] Johns C. Becoming a reflective practitioner: A reflective and holistic approach to clinical nursing, practice development, and clinical supervision. Oxford; Malden, MA: Blackwell Science; 2000.

[5] Boyd EM, Fales AW. Reflective leanring: Key to learning from experience. Journal of Humanistic Psychology. 1983; 23(2): 99-117. http://dx.doi.org/10.1177/0022167883232011

[6] Reid B. "But we're doing it already!" Exploring a response to the concept of reflective practice in order to improve its facilitation. Nurse Education Today. 1993; 13(4): 305-309. http://dx.doi.org/10. 1016/0260-6917(93) 90058-A

[7] Schön DA. The reflective practitioner: How professionals think in action. New York, NY: Basic Books; 1983.

[8] Conway J. Reflection, the art and science of nursing and the theorypractice gap. British Journal of Nursing. 1994; 3(3): 14-118.

[9] Driscoll J, Teh B. The potential of reflective practice to develop individual orthopaedic nurse practitioners and their practice. Journal of Orthopaedic Nursing. 2010; 5(2): 95-103. http://dx . doi .org/1 0.1054 /joon. 2001.0150

[10] Walsh K, McAllister M, Morgan A. Using reflective practice processes to identify practice change issues in an aged care service. Nurse Education in Practice. 2002; 2(4): 230-236. http://dx.doi . org/10.1016/S1471-5953(02)00023-9

[11] Rolfe G. Reflective practice: Where now? Nurse Education in Practice. 2002; 2(1): 21-29. PMid:19036272 http://dx . doi .org/10. 1054/nepr. 2002.0047

[12] Andrews M. Using reflection to develop clinical expertise. British Journal of Nursing. 1996; 5(8): 508-513. http://dx . doi .org/10. $12968 /$ bjon.1996.5.8.508

[13] Gustafsson C, Fagerberg I. Reflection, the way to professional development? Journal of Clinical Nursing. 2004; 13(3): 271-280. http://dx.doi.org/10.1046/j.1365-2702.2003.00880.x

[14] Nursing and Midwifery Council. Standards to support learning and assessment in practice. NMC standards for mentors, practice teachers and teachers. London: NMC. 2006.

[15] College of Nurses of Ontario. Quality assurance. Reflective practice. 2005. Available from: http://www.cno.org/docs/qa/44008_ fsRefprac.pdf

[16] Phillips T, Schostak J, Bedford H, et al. Assessment of comptencies in nursing and midwifery education and training (the Ace project). English National Board for Nursing, Midwifery and Health Visting. 1993; 4: 1-2.

[17] Cadman K, Clack E, Lethbridge Z, et al. Reflection: A casualty of modularisation? Nurse Education Today. 2003; 23(1): 11-18. http://dx.doi.org/10.1016/S0260-6917(02)00158-2

[18] Callister LC, Luthy KE, Thompson P, et al. Ethical reasoning in baccalaureate nursing students. Nursing Ethics. 2009; 16(4): 499510. PMid:19528105 http://dx.doi.org/10.1177/096973300 9104612

[19] Heath H. Reflection and patterns of knowing in nursing. Journal of Advanced Nursing. 1998; 27(5): 1054-1059. http: //dx.doi.org /10.1046/j.1365-2648.1998.00593.x

Published by Sciedu Press
[20] Vanlaere L, Gastmans C. Ethics in nursing education: Learning to reflect on care practices. Nursing Ethics. 2007; 14(6): 758-766. http://dx.doi.org/10.1177/0969733007082116

[21] Chirema KD. The use of reflective journals in the promotion of reflection and learning in post-registration nursing students. Nurse Education Today. 2007; 27(3): 192. http://dx.doi.org/10.10 $16 /$ j.nedt . 2006.04 .007

[22] Kolb D. Experiential learning: Experience as the source of learning and development. Englewood. Cliffs, NJ: Prentice-Hall; 1984.

[23] Mezirow J. Fostering critical reflection in adulthood: A guide to transformative and emancipatory learning. San Francisco, CA: JosseyBass; 1990.

[24] Boud D, Keogh R, Walker D. Reflection: Turning experience into learning. London: Kogan Page; 1985.

[25] Cirocco M. How reflective practice improves nurses' critical thinking ability. Gastroenterology Nursing. 2007; 30(6): 405-413. http: //dx.doi.org/10.1097/01.SGA.0000305221.78403.e9

[26] Benner P. From novice to expert: Excellence and power in clinical nursing practice. Menlo Park, CA: Addison-Wesley Pub. Co. 1984.

[27] Watson J. Postmodern nursing and beyond. Edinburgh: Churchill Livingstone.1999.

[28] Coffey A. The clinical learning portfolio: A practice development experience in gerontological nursing. Journal of Clinical Nursing. 2005; 14(8b): 75-83. http://dx.doi.org/10.1111/j.1365-2 $702.2005 .01279 . \mathrm{x}$

[29] Johns C. Framing learning through reflection within Carper's fundamental ways of knowing in nursing. Journal of Advanced Nursing. 1995; 22(2): 226-234. http://dx.doi.org/10.1046/j.1365-2 $648.1995 .22020226 . \mathrm{x}$

[30] Cooper C, Taft LB, Thelen M. Preparing for practice: Students' reflections on their final clinical experience. Journal of Professional Nursing. 2005; 21(5): 293-302. http://dx.doi.org/10.1016/j .profnurs.2005.07.002

[31] Davies E. Reflective practice: A focus for caring. Journal of Nursing Education. 1995; 34(4): 167-174. PMid:7782884

[32] Donovan MO. Implementing reflection: Insights from preregistration mental health students. Nurse Education Today. 2007; 27(6): 610-616. http://dx.doi.org/10.1016/j.nedt. 2006 .09 .001

[33] Duke S, Appleton J. The use of reflection in a palliative care programme: A quantitative study of the development of reflective skills over an academic year. Journal of Advanced Nursing. 2000; 32(6): 1557-1568. http://dx.doi.org/10.1046/j.1365-2648. 2000 $.01604 . \mathrm{x}$

[34] Durgahee T. Reflective practice: Nursing ethics through story telling Nursing Ethics. 1997; 4(2): 135-146. http://dx.doi.org/10.11 $77 / 096973309700400205$

[35] Fakude LP, Bruce JC. Journaling: A quasi-experimental study of student nurses' reflective learning ability. Curationis. 2003; 26(2): 49-55. http://dx.doi.org/10.4102/curationis.v26i2.783

[36] Gibbs G. Learning by doing: A guide to teaching and learning methods. Oxford: Further EducationalUnit. 1988.

[37] Flanagan J. Patient and nurse experiences of theory-based care. Nursing Science Quarterly. 2009; 22(2): 160-172. http://dx.doi.org /10.1177/0894318409331937

[38] Newman MA. Health as expanding consciousness. (2 ed.). Sudsbury, MA: Jones and Bartlett Publishers; 2000.

[39] Forneris SG, Peden-McAlpine C. Evaluation of a reflective learning intervention to improve critical thinking in novice nurses. Journal of Advanced Nursing. 2007; 57(4): 410-421. http://dx.doi.org/1 $0.1111 / \mathrm{j} .1365-2648.2007 .04120 . \mathrm{x}$ 
[40] Forneris SG, Peden-McAlpine CJ. Contextual learning: A reflective learning intervention for nursing education. International Journal of Nursing Education Scholarship. 2006; 3(1): 1-18. http: //dx.doi.org/10.2202/1548-923X.1254

[41] Glaze JE. Reflection as a transforming process: Student advanced nurse practitioners' experiences of developing reflective skills as part of an MSc programme. Journal of Advanced Nursing. 2001; 34(5): 639-647. http://dx.doi.org/10.1046/j.1365-2648. 2001.01793.x

[42] Glaze JE. Stages in coming to terms with reflection: Student advanced nurse practitioners' perceptions of their reflective journeys. Journal of Advanced Nursing. 2002; 37(3): 265-272. http: //dx.doi.org/10.1046/j.1365-2648.2002.02093.x

[43] Graham IW, Andrewes T, Clark L. Mutual suffering: A nurse's story of caring for the living as they are dying. International Journal of Nursing Practice. 2005; 11(6): 277-285. http://dx.doi.org/10 1111/j.1440-172X.2005.00535.x

[44] Parse RR. Man-living-health: A theory of nursing. New York, NY: Wiley; 1981.

[45] Parse RR. Nursing science: Major paradigms, theories, and critiques. Philadelphia, PE: W.B. Saunders; 1987.

[46] Parse RR. Human becoming: Parse's theory of nursing. Nursing Science Quarterly. 1992; 5(1): 35-42. http://dx.doi.org/10.11 77/089431849200500109

[47] Parse RR. Quality of life for persons living with Alzheimer's disease: The human becoming perspective. Nursing Science Quarterly. 1996; 9(3): 126-133. http://dx.doi.org/10.1177/0894318496009 00312

[48] Parse RR. The human becoming school of thought: A perspective for nurses and other health professionnals. Thousand Oaks, CA: Sage; 1998.

[49] Parse RR. Hope: An interntional human becoming perspective. Sudbury, MA: Jones \& Bartlett; 1999.

[50] Hartrick G. Developing health promoting practice with families: One pedagogical experience. Journal of Advanced Nursing. 2000; 31(1): 27-34. http://dx.doi.org/10.1046/j.1365-2648. 20 $00.01263 . \mathrm{x}$

[51] Smith R. Potentials for emporwerment in critical education research. Australian Edicational Researcher. 1993; 20(2): 75-93. http://dx.doi.org/10.1007/BF03219544

[52] Heidari F, Galvin K. Action learning groups: Can they help students develop their knowledge and skills? Nurse Education in Practice. 2003; 3(1): 49-55. http://dx.doi.org/10.1016/S1471-595 3(02) 00054-9

[53] Honey M, Waterworth S, Baker H, et al. Reflection in the disability education of undergraduate nurses: An effective learning tool? Journal of Nursing Education. 2006; 45(11): 449-453. PMid:17120862

[54] Tripp D. Critical incidents in teaching. London: Routledge. 1993.

[55] Ip WY, Liu MH, Wai TC, et al. Promoting self-reflection in clinical practice among Chinese nursing undergraduates in Hong Kong. Contemporary Nurse. 2012; 41(2): 253-262. PMid:22800391 http: //dx.doi.org/10.5172/conu.2012.41.2.253

[56] Jasper MA. Nurses' perceptions of the value of written reflection. Nurse Education Today. 1999; 19(6): 452-463. http://dx.doi.o rg/10.1054/nedt.1999.0328

[57] Jensen SK, Joy C. Exploring a model to evaluate levels of reflection in baccalaureate nursing students' journals. Journal of Nursing Education. 2005; 44(3): 139-142. PMid:15787024

[58] Mezirow J. A critical theory of adult learning and education. Adult Education. 1981; 32(1): 3-24. http://dx.doi.org/10.1177/0 74171368103200101
[59] Mantzoukas S, Jasper MA. Reflective practice and daily ward reality: A covert power game. Journal of Clinical Nursing. 2004; 13(8): 925933. PMid: 15533098 http://dx.doi.org/10.1111/j.1365-2 702.2004.01008.x

[60] Martin GW, Mitchell G. A study of critical incident analysis as a route to the identification of change necessary in clinical practice: Addressing the theory-practice gap. Nurse Education in Practice. 2001; 1(1): 27-34. PMid:19036240 http://dx.doi.org/10.10 54/nepr. 2001.0006

[61] Page S, Meerabeau L. Achieving change through reflective practice: Closing the loop. Nurse Education Today. 2000; 20(5): $365-$ 372. PMid:10895118 http://dx.doi.org/10.1054/nedt. 2000 .0430

[62] Paget T. Reflective practice and clinical outcomes: Practitioners' views on how reflective practice has influenced their clinical practice. Journal of Clinical Nursing. 2001; 10(2): 204-214. PMid:11820341 http://dx.doi.org/10.1046/j.1365-2702.2001.00482.x

[63] Morgan DL. Practical strategies for combining qualitative and quantitative methods: Applications to health research. Qualitative Health Research. 1998; 8(3): 362-376. http://dx.doi.org/10.1177/1 04973239800800307

[64] Peden-McAlpine C, Tomlinson PS, Forneris SG, et al. Evaluation of a reflective practice intervention to enhance family care. Journal of Advanced Nursing. 2005; 49(5): 494-501. http://dx.doi.org/1 $0.1111 / j .1365-2648.2004 .03322 . x$

[65] Schön DA. Educating the reflective practitioner: Toward a new design for teaching and learning in the professions. (1st ed.). San Francisco, CA: Jossey-Bass; 1987.

[66] Perry L. Critical incidents, crucial issues: Insights into the working lives of registered nurses. Journal of Clinical Nursing. 1997; 6(2): 131-137. PMid:9188351 http://dx.doi.org/10.1111/j .1365-2702.1997.tb00295.x

[67] Platzer H, Blake D, Ashford D. An evaluation of process and outcomes from learning through reflective practice groups on a postregistration nursing course. Journal of Advanced Nursing. 2000; 31(3): 689-695. PMid:10718889 http://dx.doi.org/10.1046 /j.1365-2648.2000.01337.x

[68] Schuessler JB, Wilder B, Byrd LW. Reflective journaling and development of cultural humility in students. Nursing Education Perspectives. 2012; 33(2): 96-99. PMid:22616407 http://dx. doi .org/10.54 80/1536-5026-33.2.96

[69] Spencer N, Newell R. The use of brief written educational material to promote reflection amongst trained nurses: A pilot study. Nurse Education Today. 1999; 19(5): 347-356. PMid:10693482 http://dx.doi.org/10.1054/nedt.1999.0373

[70] Wong FKY, Kember D, Chung LYF, et al. Assessing the level of student reflection from reflective journals. Journal of Advanced Nursing. 1995; 22(1): 48-57. PMid:7560535 http://dx.doi.org/10.10 46/j.1365-2648.1995.22010048.x

[71] Mezirow J. Transformative dimensions of adult learning. San Francisco, CA: Jossey-Bass; 1991.

[72] Taylor B. Identifying and transforming dysfunctional nurse-nurse relationships through reflective practice and action research. International Journal of Nursing Practice. 2001; 7(6): 406-413. PMid:11785443 http://dx.doi.org/10.1046/j.1440-172X. 2001.00323. $\mathrm{x}$

[73] Teekman B. Exploring reflective thinking in nursing practice. Journal of Advanced Nursing. 2000; 31(5): 1125-1135. http: //dx.doi.o $\mathrm{rg} / 10.1046 / \mathrm{j} .1365-2648.2000 .01424 . \mathrm{x}$

[74] Dervin B. From the mind's eye of the user: The sense-making qualitative-quantitative methodology. In J. D. Glazier \& R. R. Powell 
(dir.), Qualitative research in information management. Englewood, CO: Libraries Unlimited; 1992.

[75] Torsvik M, Hedlund M. Cultural encounters in reflective dialogue about nursing care: a qualitative study. Journal of Advanced Nursing. 2008; 63(4): 389-396. PMid:18727766 http://dx.doi.org/10. $1111 / j .1365-2648.2008 .04723 . x$
[76] Wong FKY, Loke AY, Wong M, et al. An action research study into the development of nurses as reflective practitioners. Journal of Nursing Education. 1997; 36(10): 476-481. PMid:9413818

[77] Dewey J. How we think: A restatement of the reflective thinking to the educative process. Boston, MA: Heath. 1910/1933. PMid:17744061 http://dx.doi.org/10.1037/10903-000 